\title{
Japanese Horsehair Worms (Nematomorpha) from the Lake Biwa Museum
}

\author{
Andreas Schmidt-Rhaesa \\ Zoomorphology and Systematics, Faculty of Biology, University of Bielefeld, \\ PO Box 100131, D-33501 Bielefeld, Germany \\ E-mail: a.schmidt-rhaesa@uni-bielefeld.de
}

(Received 6 March 2003; Accepted 10 October 2003)

\begin{abstract}
From Japan, 11 species of freshwater Nematomorpha have been described to date, but there are very few photographic documentations of any of them. This investigation describes specimens from the Lake Biwa Museum (Shiga Prefecture, Japan) and supplies the first SEM pictures and additional data for the species Chordodes fukuii Inoue, 1951, Japanese specimens of $C$. japonensis Inoue, 1952, and Paragordionus kawamurai Yamaguti, 1943. Two specimens likely belong to the genus Gordionus, which has not been reported from Japan before, but they could not be determined to the species level. Several specimens belonging to the genus Gordius could not be assigned to a certain species. This is due to general problems with the status of several Gordius species arising from the scarcity of taxonomically relevant characters.
\end{abstract}

Key Words: Nematomorpha, Gordiida, horsehair worms, Japan, Shiga Prefecture, Lake Biwa, taxonomy, SEM, mantids.

\section{Introduction}

From Japan, 11 species of Nematomorpha have been described to date: Gordius fulgur Baird, 1861; G. japonicus Inoue and Fukui, 1953; G. cavernarum Inoue, 1972; G. luteopunctatus Inoue, 1979; G. ogatai Inoue, 1979; Chordodes silvestri Camerano, 1895; C. fukuii Inoue, 1951; C. japonensis Inoue, 1952; Parachordodes lestici Heinze, 1935; P. okadai Inoue, 1955; and Paragordionus kawamurai Yamaguti, 1943 [for overviews, see Inoue (1955) and Fukui and Inoue (1973)]. Of these species, only the cuticle of Korean specimens of Chordodes japonensis has been documented photographically (Baek 1993). Knowledge of the structure of the cuticle and of the posterior end, especially in males, is essential for the identification and characterization of nematomorph species. Light microscopical preparations are useful, but in general the high magnification available with scanning electron microscopy (SEM) is the most reliable way to observe characters in Nematomorpha (SchmidtRhaesa 2001a). The investigation of 20 specimens of Nematomorpha from the Lake Biwa Museum has made it possible to supply the first light microscopical and SEM documentation of these features from Japanese specimens. 


\section{Materials and Methods}

All investigated specimens were collected in Shiga Prefecture, in west-central Japan, and belong to the collections of the Lake Biwa Museum in Kusatsu, Shiga Prefecture, where all slide preparations and SEM stubs have also been deposited; the lot numbers given (LBM no.) are temporary ones. Specimens were prepared for scanning electron microscopy (SEM) and/or light microscopy (LM). For SEM, parts of the body or superficial cuticular samples were dehydrated in an increasing ethanol series, transferred into liquid $\mathrm{CO}_{2}$ and dried in a critical point dryer (Balzers CPD 030), coated with gold for 300 seconds at $30 \mathrm{~mA}$ in a sputter coater (Balzers SCD 005), and observed at $15 \mathrm{kV}$ with a Hitachi SEM 450 scanning electron microscope. For LM, tangential sections of cuticle were removed from the midbody. Tissue adhering to the cuticle was removed mechanically and the cuticle was mounted in glycerine jelly for permanent storage.

\section{Results and Discussion}

Chordodes fukuii Inoue, 1951

(Fig. 1A-D)

Materials investigated. Two females, outdoor facilities of Lake Biwa Museum, Oroshimo, Kusatsu city, from praying mantid Tenodera sinensis Saussure, 1871, coll. Y. Sugino (LBM no. 11); 1 female, concrete pool behind Lake Biwa Museum, Oroshimo, Kusatsu city, coll. M. J. Grygier (LBM no. 16); 1 female, artificial stream in front of Lake Biwa Museum, Oroshimo, Kusatsu city, collector unrecorded (LBM no. 18); 1 male, watercourse close to shore of Lake Biwa, Kitahira, Shiga town, coll. H. Hamaguchi (LBM no. 19).

Description. Body colour light to medium brown. Anterior end white but blending into main body colour without sharp transition. Anterior end tapering. Female posterior end swollen, male posterior end rounded, without tail lobes. Cuticle with three types of areole (structures raised above body surface). Type 1 slender and higher (approximately $5 \mu \mathrm{m}$ ) than others (Fig. 1A-D); basal part smooth, apical margin bearing ring of very short processes (Fig. 1B, C), though sometimes not very conspicuous (Fig. 1D). Type 1 areoles distributed in clusters among type 2 areoles (Fig. 1A), latter being lower (Fig. 1A-C) or even almost level with body surface (Fig. 1D). Surface of type 2 areoles densely covered by small, very short processes, those usually even shorter than those on type 1 areoles (Fig. 1B, D). Type 3 areoles similar to type 2, but bearing longer central projection (tubercle) on top (Fig. 1C), scattered among them. Cuticle between areoles covered by longitudinal cords (Fig. 1D).

Dimensions. The four females were $210,235,235$, and $245 \mathrm{~mm}$ in length and 1 , $1.2,1.5$, and $1.2 \mathrm{~mm}$ in diameter, respectively. The male was $150 \mathrm{~mm}$ in length and $0.7 \mathrm{~mm}$ in diameter.

Discussion. Chordodes fukuii has been reported by Inoue (1951, 1952a, 1955, 1965, 1994). The general characteristics of the cuticle as figured by Inoue (1952a, 1965) are confirmed; however, the slender tubercles he figured between pairs of type 2 areoles were found only on top of some single areoles of this type. This pat- 

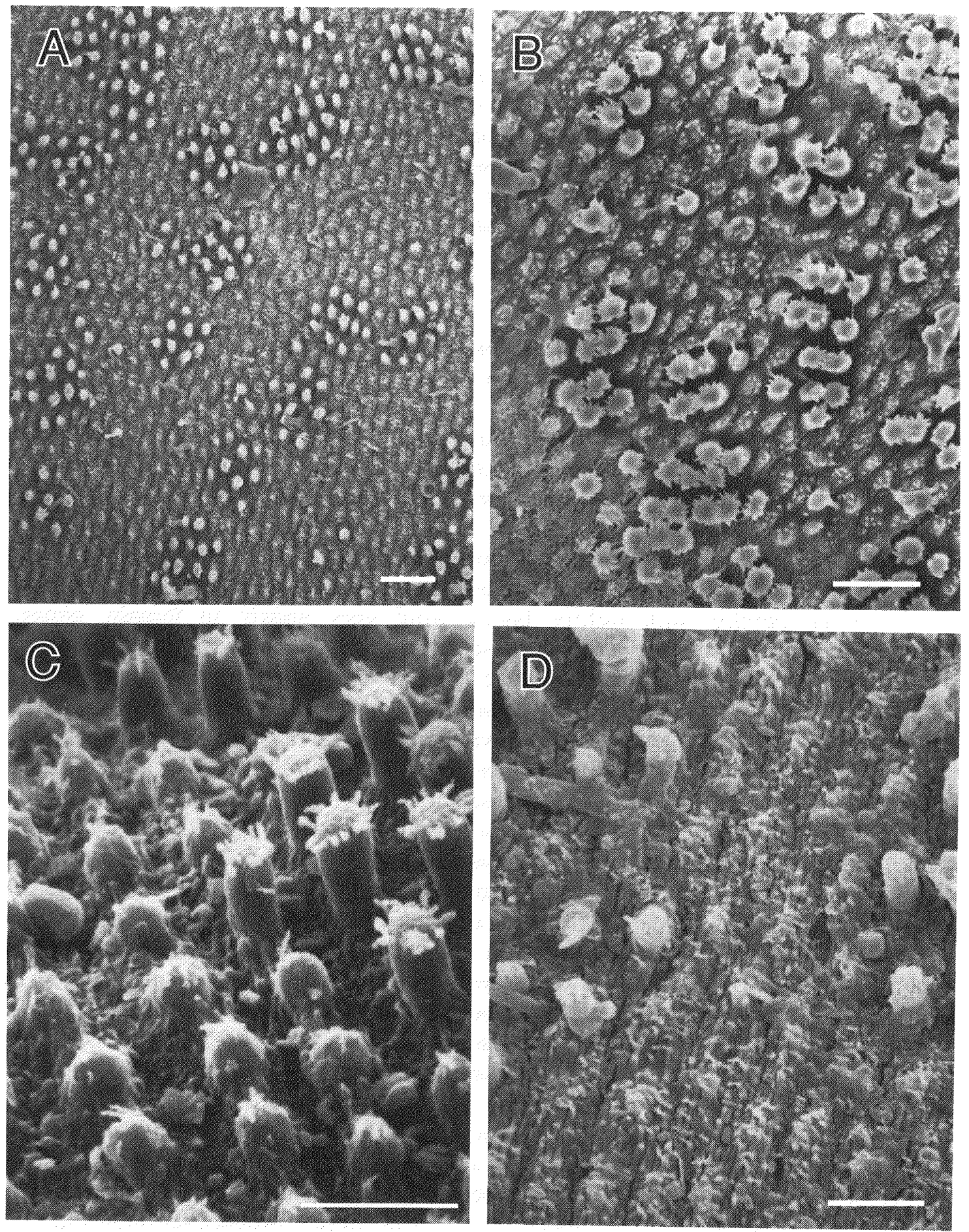

Fig. 1. Chordodes fukuit, SEM photographs of cuticle. A, low magnification showing clusters of crowned areoles between regions with flat areoles (LBM no. 16); B, cluster of crowned areoles in higher magnification, cuticle partly covered with dirt (no. 11); C, crowned areoles in lateral view (no. 18); D, magnification of flat areoles (no. 16). Scales: A, B, $20 \mu \mathrm{m} ; \mathrm{C}, \mathrm{D}, 10 \mu \mathrm{m}$. 
tern is familiar from other species of the genus Chordodes [e.g., Schmidt-Rhaesa (2002a) and Chordodes japonensis below]. The type 1 areole corresponds to what has been called "crowned areoles" (Schmidt-Rhaesa 2002b) and is diagnostic and autapomorphic for the genus Chordodes. In most other species, the apical projections on crowned areoles are considerably longer. Additionally, crowned areoles often form characteristic clusters (compare with $C$. japonensis below), which never occur in $C$. fukuii. The species $C$. fukuii has been reported from Akita, Tochigi, Toyama, and Yamanashi Prefectures. The new report from Shiga Prefecture is a new western and southern range limit.

\section{Chordodes japonensis Inoue, 1952}

(Figs 2, 3)

Materials investigated. One male, from cigarette ash disposal bucket at gasoline station, Shimosakamoto, Otsu city, coll. Y. Yamamoto (LBM no. 13); 1 female, from praying mantid Hierodula patellifera (Serville, 1839), Hiyoshidai, Otsu city, coll. S. Arita (LBM no. 15).

Description. General shape of body corresponding to that of Chordodes fukuii. Body not uniformly coloured, but with numerous dark patches. In male, contrast between dark patches and lighter background very sharp; in female, general colour darker than in male and contrast differences not as pronounced. Cuticle covered by five types of areole. Crowned areoles most conspicuous, occurring always in clusters of two with central tubercle enclosed between them (Figs 2A-D, 3A). Apical filaments longer than in crowned areoles of $C$. fukuii, originating from flat apical surface of areoles, this surface also ornamented by grooves separating bases of filaments (Fig. 3A). Crowned areoles with moderately long apical filaments $(1.5-2.5 \mu \mathrm{m})$ occurring over the whole body surface (Figs $2 \mathrm{C}, \mathrm{D}, 3 \mathrm{~A}$ ), but second type of crowned areole with very long filaments (up to $200 \mu \mathrm{m}$ ) occurring in double row along both sides of ventral midline (Fig. 2A, B). Both types of crowned areole surrounded by circle of elevated areoles carrying short apical projections originating from small central area or, in fewer cases, from whole apical surface of areole (Figs 2A-D, 3A). Clusters of crowned and elevated areoles surrounded by numerous rounded areoles, these latter being clearly elevated above cuticular surface but never as much as previously described areolar types (Fig. 2A, C). Some rounded areoles carrying apical fingerlike tubercle ("tubercle areoles"; Figs 2A, C, 3B).

Dimensions. The female was $275 \mathrm{~mm}$ in length (in life, $315 \mathrm{~mm}$ ) and $1.6 \mathrm{~mm}$ in diameter. The male was $295 \mathrm{~mm}$ in length and $1 \mathrm{~mm}$ in diameter.

Discussion. Previous reports on the cuticular structure of Japanese (Inoue 1952b) and Korean (Baek 1993) specimens of Chordodes japonensis have also described five areolar types, but the results differ from the present observations in detail. Crowned areoles were described by both authors, but only Baek (1993) noted that two types are present and that those with longer apical filaments are restricted to the ventral midline. The elevated type surrounding the crowned areoles was also recognized by both authors. An areolar type that they described as type 3 consisted of a paired structure. This does not correspond to a surface structure of the cuticle, but is a structure beneath the cuticle (see Schmidt-Rhaesa 2001a; also 

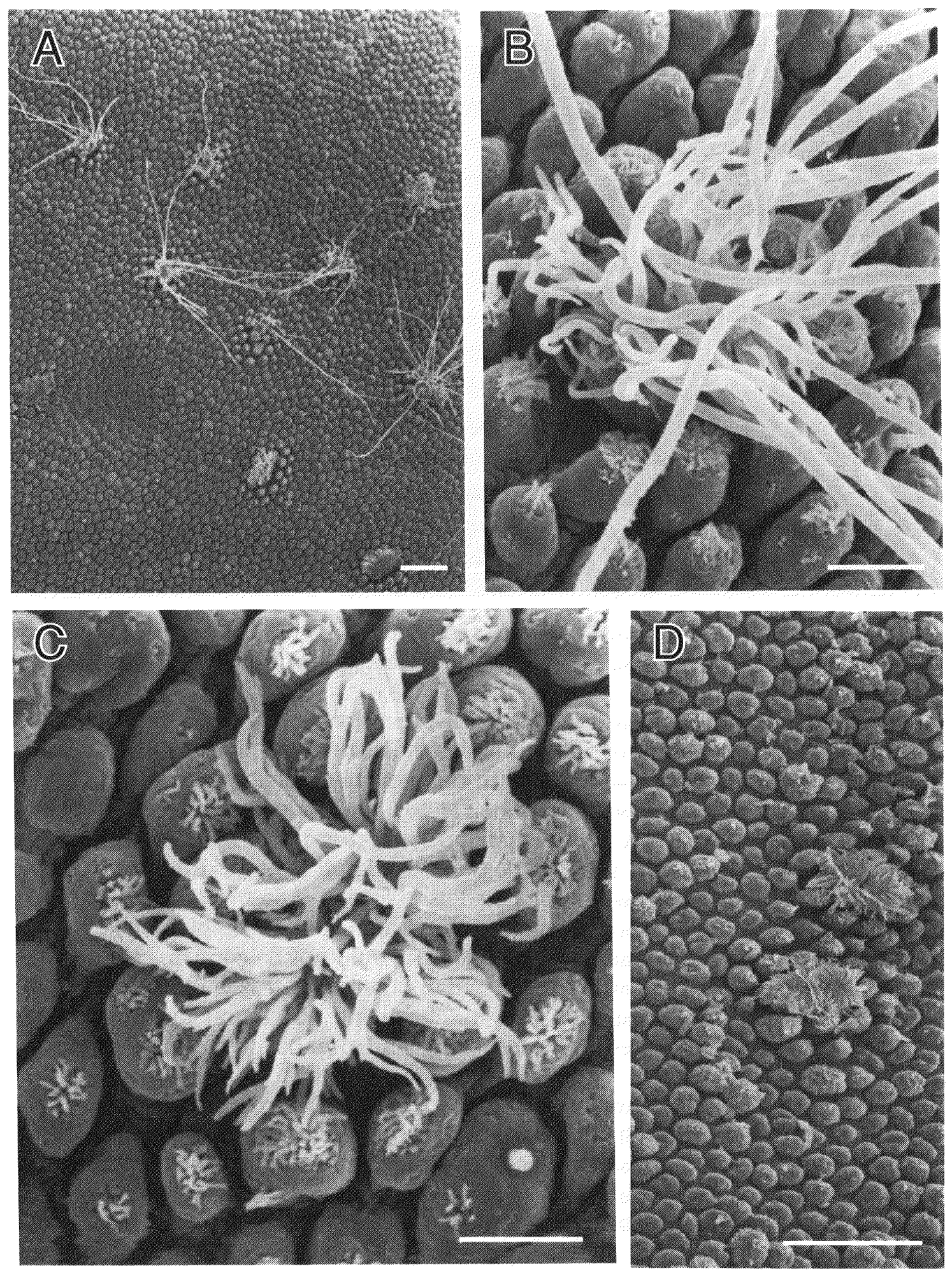

Fig. 2. Chordodes japonensis, SEM photographs of cuticle. A, low magnification showing crowned areoles with long apical filaments along ventral midline (LBM no. 15); B, detail of crowned areoles with long filaments and surrounding areoles (no. 15); C, crowned areoles with short filaments from lateral part of the body (no. 13); D, crowned areole with short filaments and surrounding areoles (no. 15). Scales: A, D, $50 \mu \mathrm{m} ; \mathrm{B}, \mathrm{C}, 10 \mu \mathrm{m}$. 

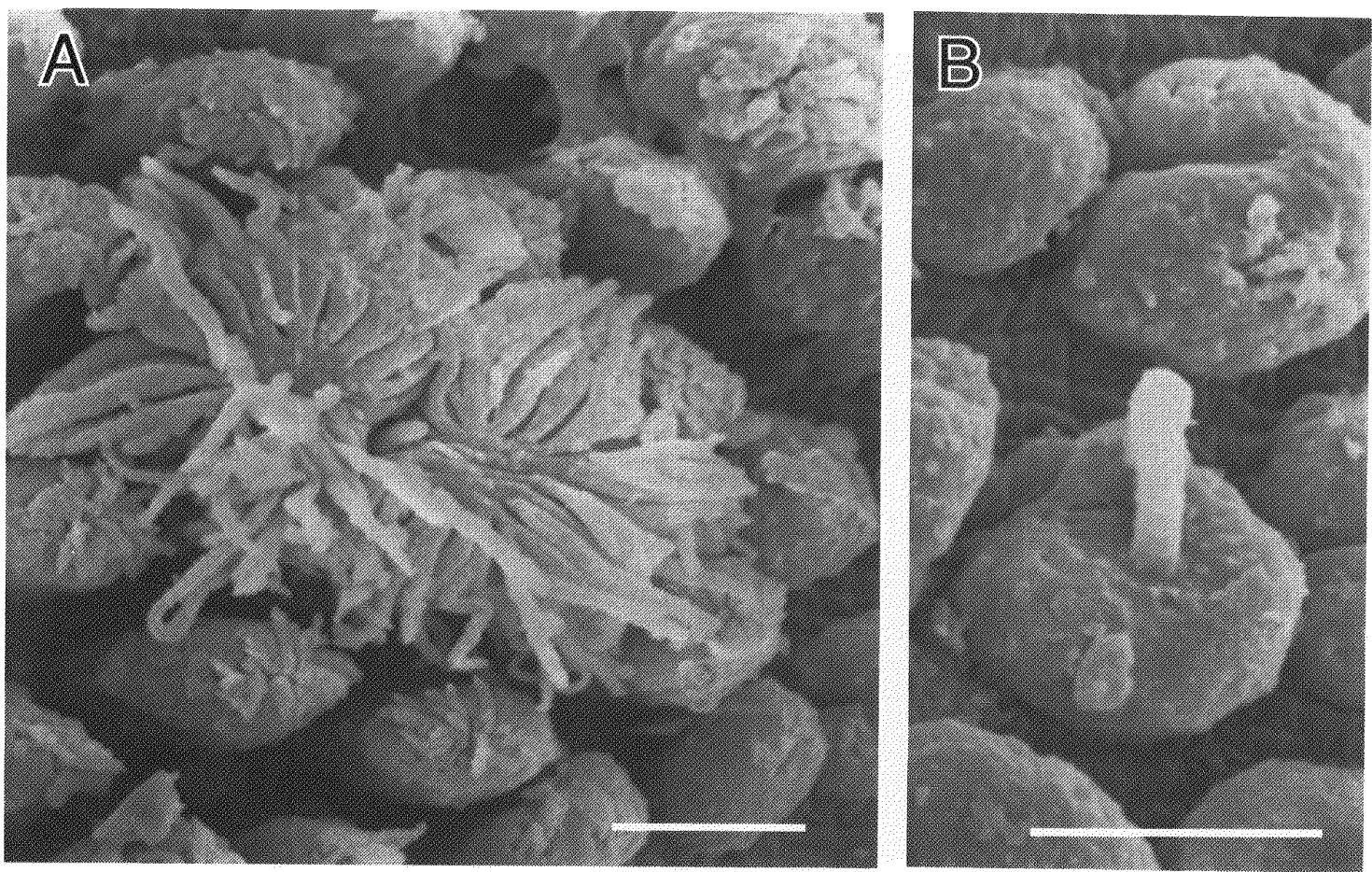

Fig. 3. Chordodes japonensis, SEM photographs of cuticle. A, crowned areoles, with tubercle between two areoles clearly visible (LBM no. 13); B, tubercle areole (no. 13). Scales: $10 \mu \mathrm{m}$.

Paragordionus kawamurai in Fig. 4B) and is, therefore, not a type of areole. Tubercle areoles were recognized by all authors as a distinct type of areole. Inoue (1952b) included areoles carrying a solid spine in this type of areole. Spines were not found either in this investigation or that of Baek (1993). This may be due to the scarcity of such "spine areoles" or to different distribution patterns along the body axis [see, e.g., Schmidt-Rhaesa (2002a) for Chordodes queenslandi Schmidt-Rhaesa, 2002]. The abundant "simple" areoles were not listed as a special type by Inoue (1952b), who, however, listed another areolar type scattered among the "simple". ones, but further elevated and often clustered in pairs. This could not be confirmed here. Some areoles seem to be elevated slightly more than others, but this could be due to variation among the "simple" areoles, and no clustering was found in the specimens investigated here. The different terminology and numbering of areolar types is summarized in Table 1.

The areolar types documented here correspond to structures well known in other species (e.g., Schmidt-Rhaesa 2002a). Crowned areoles often form typical clusters together with elevated areoles. The dimorphism of crowned areoles seems to be present in more species than previously suspected, having been overlooked in some (Schmidt-Rhaesa 2002a, unpublished observations). Tubercle areoles and spine areoles are also part of the usual set of characters found in a number of species of Chordodes. The pattern of dark patches is also present in several species of this genus but has not been reported before for $C$. japonensis. 
Table 1. Comparison of areolar types in Chordodes japonensis as recognized by Inoue (1952), Baek (1993), and in this investigation.

\begin{tabular}{|c|c|c|c|c|}
\hline \multirow{2}{*}{$\begin{array}{c}\text { This investigation } \\
\text { Areole type }\end{array}$} & \multicolumn{2}{|c|}{ Inoue (1952) } & \multicolumn{2}{|c|}{ Baek (1993) } \\
\hline & No. & Status* & No. & Status* \\
\hline Crowned areoles with short projections & 1 & + & 1 & + \\
\hline $\begin{array}{l}\text { Crowned areoles with long projections } \\
\text { (in ventral midline) }\end{array}$ & & - & 1 & + \\
\hline Elevated areoles surrounding crowned areoles & 2 & + & 2 & + \\
\hline [Subsurface structures, no areoles] & 3 & + & 3 & t \\
\hline Tubercle areoles & 4 & + & 4 & + \\
\hline [Spine areoles] & 4 & + & & - \\
\hline [Paired elevated areoles] & 5 & + & & _- \\
\hline "Simple" areoles & - & + & 5 & + \\
\hline
\end{tabular}

*Status: +, present; -, absent.

\section{Paragordionus kawamurai Yamaguti, 1943}

(Fig. 4A-C)

Materials investigated. Two males, small stream in Sonyurin Valley, Kôzuhara, Ibuki town, $970 \mathrm{~m}$ a.s.l., coll. S. Uchida et al. (LBM no. 4); 2 males, 2 females, Hiro Valley, Mt. Bunaga, Shiga town, $920 \mathrm{~m}$ a.s.l., coll. S. Uchida et al. (LBM no. 5).

Description. Body colour in all males medium brown; in females slightly lighter. Anterior end slightly tapered. Anterior tip white; dark collar (as present in other species of this genus) absent. Posterior end of males with two tail lobes of moderate length (shorter than body diameter at level of cloacal opening; appoximately $250 \mu \mathrm{m}$ ) (Fig. 4C). Cloacal opening on ventral side, oval and surrounded by circumcloacal spines (Fig. 4C). Paired fields of unbranched bristles anterolateral of cloacal opening ending at level of cloacal opening (Fig. 4C). Cuticle on ventral side of posterior end between bristlefields and posterior tip smooth and not formed into areoles (Fig. 4C). Short spines found in this smooth region, most abundantly on inner face of tail lobes (Fig. 4C). Elsewhere, cuticle formed into flat, polygonal areoles (Fig. 4A, B), with short cuticular bristles in narrow interspaces. Some areoles slightly larger and more elevated than remaining ones and always forming clusters of at least two areoles (Fig. 4A, B). These areoles also darker than surrounding ones (Fig. 4B), with short tubercle always present between them (Fig. 4A, B). Such short tubercle also often present between two areoles of flat type (Fig. 4A, B). In light microscopical cuticle preparations, additional subsurface structures observed (Fig. 4B). Keeled areoles as observed by Yamaguti (1943) (see below) not observed in this investigation, but the region in which they could be expected was not investigated.

Dimensions. The four males were $110,190,195$, and $220 \mathrm{~mm}$ in length and 0.5 , $0.7,0.7$, and $0.9 \mathrm{~mm}$ in diameter, respectively. The two females were 200 and $260 \mathrm{~mm}$ in length and $1.2 \mathrm{~mm}$ in diameter.

Discussion. Apart from P. kawamurai, the genus Paragordionus includes four 

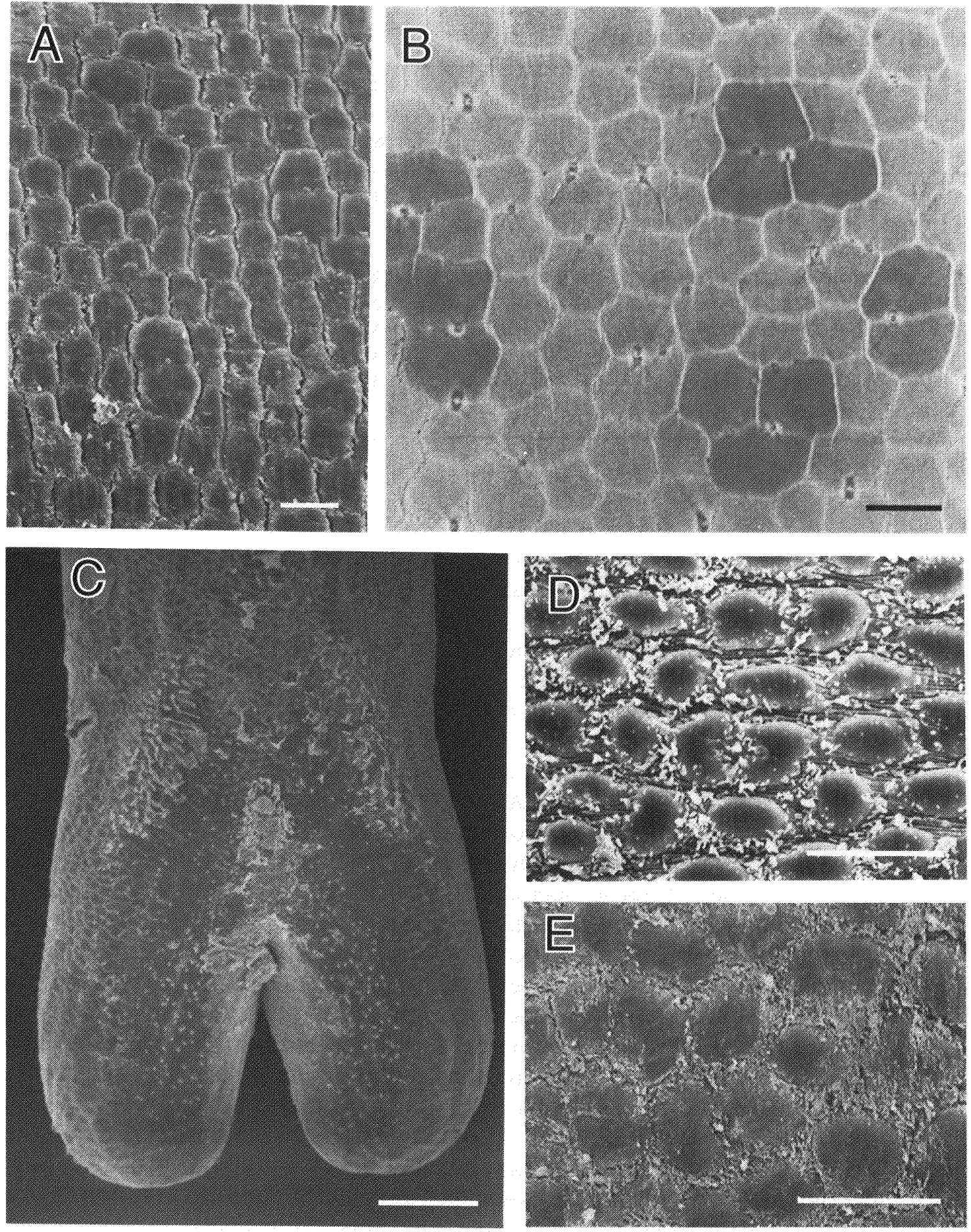

Fig. 4. Paragordionus kawamurai and Gordionus sp. A-C, Paragordionus kawamurai: A, cuticle with clusters of two slightly larger areoles enclosing a tubercle (LBM no. 4); B, darker colour of clustered (clusters of two or three) areoles shown in cuticular preparation for light microscopy - note additional subcuticular structures not visible with SEM (no. 4); C, ventral view of posterior end of male (no. 5), with cloacal opening, tail lobes, and cuticular bristles and spines. D, E, Gordionus sp. (D, no. 17; E, no. 8), simple areoles on cuticle. All except B with SEM. Scales: A, B, D, E, $20 \mu \mathrm{m} ; \mathrm{C}, 100 \mu \mathrm{m}$. 
species found in Central Europe (Schmidt-Rhaesa 1997). However, only two species, the type species $P$. dispar (Müller, 1927) and P. vejdovsky (Janda, 1895), display a pattern of cuticular ornamentation that can be regarded as characteristic and autapomorphic for the genus (Schmidt-Rhaesa 2002b). This is the clustering of several areoles into larger clusters. In this respect, $P$. kawamurai is a typical member of the genus. Schmidt-Rhaesa (2002b) has pointed out problems in interpreting the situation where a tubercle is found between two areoles, because this arrangement is not always connected with a distinct type of areole, but can be present as well between "simple" areoles, as is also expressed in P. kawamurai. This pattern (called a "megareolar" pattern) occurs in several other genera. The modification of the areoles in the ventral region anterior of the cloacal opening is very important (Yamaguti 1943); these areoles have a kind of keel on top, which is oriented parallel to the longitudinal axis of the animal. This structure corresponds to what have been called "adhesive warts" and is elsewhere only known from species of Gordionus (Schmidt-Rhaesa 2002b).

All specimens of $P$. kawamurai found to date have been collected in elevated regions, at heights of almost $1,000 \mathrm{~m}$ a.s.l. in the present investigation and $1,500 \mathrm{~m}$ by Yamaguti (1943). Although there have been only a few records of this species, the available data suggest a preference for mountainous habitats or suggest a restriction to host insects (species yet unknown) that prefer mountainous habitats.

\section{Gordionus sp.}

(Fig. 4D, E)

Materials investigated. One female, Ôkame Valley, Mt. Hira, Ôtsu city, $880 \mathrm{~m}$ a.s.l., coll. S. Uchida (LBM no. 8); 1 female, tributary of Tenjin River behind Ogura Shrine, Ôgi 4-chôme, Ôtsu city, coll. Y. Kusuoka (LBM no. 17).

Description. Cuticle bearing one type of areole, typically moderately elevated and of varying shape and size. Clear interareolar space present, with short bristles therein. Some areoles appearing clustered into megareolar pattern (see discussion of Paragordionus kawamurai above), but not very distinctly.

Discussion. The presence of only one type of areole is characteristic for the genera Neochordodes and Gordionus. Because Neochordodes occurs only in North and South America (Schmidt-Rhaesa 2002b), the two Japanese specimens most likely represent the genus Gordionus, which has not been reported from Japan before. A clear identification can only be made when males become available, because males show additional characters of the genus, whereas females are relatively poor in taxonomically relevant features. The presence or absence of the megareolar pattern in species of Gordionus has received attention only recently, and the importance of this pattern for taxonomy is still unclear (Schmidt-Rhaesa 2001b).

\section{Gordius spp.}

Material investigated. One male, Kusano River, Azai town, $250 \mathrm{~m}$ a.s.l., coll. S. Uchida (LBM no. 1); 2 females, small tributary of Chaya River, Eigenji town, 430 
m a.s.l., coll. S. Uchida (LBM no. 2); 1 male, 1 female, woodland path to Torigoe Pass, Mt. Kanakuso, $800 \mathrm{~m}$ a.s.l., Azai town, coll. S. Uchida (LBM no. 3); 1 female, Lake Biwa shore, Sengoku-daira, Ôra, Nishiazai town, coll. S. Uchida (LBM no. 9); 1 female, in rainwater-filled styrofoam box outside private house in Shinji, Konan town, coll. A. Fukunaga (LBM no. 10); 1 female, small pond at mouth of small stream close to shore of Lake Biwa, Daimotsu, Shiga town, coll. M. Tago (LBM no. 12); 1 female, in rain puddle on concrete close to private house at Kita-Funaki, Adogawa town, coll. K. Kawamoto (LBM no. 20).

Discussion. In the collection of the Lake Biwa Museum, several specimens with a smooth cuticle are present, the males possessing a structure called a postcloacal crescent at the posterior end, but with no other cuticular structures. A smooth cuticle and a postcloacal crescent (in combination with rounded tail lobes in males) are present only in the genus Gordius. Five species of Gordius have been described from Japan: G. fulgur, G. japonicus, G. cavernarum, G. luteopunctatus, and G. ogatai (Inoue 1955, 1972, 1979; Inoue and Fukui 1953). Gordius cavernarum is characterized by a precloacal V-shaped row of bristles, which is otherwise known in this form only in Gordius difficilis Montgomery, 1898 (see Smith 1994) and, in a U-shaped form, from Gordius paranensis Camerano, 1892 (see Schmidt-Rhaesa et al. 2000). Gordius luteopunctatus is the only Japanese species in which flat, polygonal areoles are present, but because they are present in other species of Gordius outside Japan, it is doubtful whether $G$. luteopunctatus is a truly a distinct species. The three remaining species, G. fulgur, G. japonicus, and G. ogatai, were described as having a smooth cuticular surface and no posterior structures besides the postcloacal crescent. There is some indication that size can differ intraspecifically (Schmidt-Rhaesa 1997); therefore, characters such as the length of the tail lobes or the shape of the postcloacal crescent may be of doubtful value in separating species. In general, species of the genus Gordius that possess no cuticular structures are extremely hard to characterize. Specimens from Korea that are similar to the present ones were referred to the (otherwise Nearctic) species G. robustus Leidy, 1851 by Baek and Noh (1992). On this weak basis, it is not possible to assign the specimens from the Lake Biwa Museum to any particular species of Gordius, but a reinvestigation of the holotypes of Japanese Gordius speices could be helpful. A similar case is present in Inoue's (1994) investigation of horsehair worms from the Toyama Science Museum, in which he listed 12 Gordius specimens but could not assign any of them to a species.

\section{Acknowledgements}

Many thanks to Dr. Mark J. Grygier of the Lake Biwa Museum for the opportunity to investigate that museum's nematomorph collection, his constant interest in the progress of the work, his examination of a draft of the manuscript, and his help in finding some "hidden" literature.

\section{References}

Baek, K. M. 1993. Two species of genus Chordodes (Gordioidea, Nematomorpha) from Korea. 
The Korean Journal of Systematic Zoology 9: 221-228.

Baek, K. M. and Noh, Y. T. 1992. Two species of genus Gordius (Gordioidea, Nematomorpha) from Korea. The Korean Journal of Systematic Zoology 8: 223-230.

Fukui, T. and Inoue, I. 1973. Nematomorpha. Pp. 269-271. In: Uéno, M. (Ed.) Freshwater Biology of Japan. Hokuryukan, Tokyo. [In Japanese]

Inoue, I. 1951. An additional new species of Gordiacean parasitizing praying mantids, and the domestic and overseas distribution of the genus Chordodes. Zoological Magazine (Tokyo) 60: 32. [In Japanese]

Inoue, I. 1952a. Classification of Japanese Chordodes (Gordiacea). Zoological Magazine (Tokyo) 61: 27-32. [In Japanese with English résumé]

Inoue, I. 1952b. On a new species of Chordodes (Gordiacea) from Japan. Annotationes Zoologicae Japonenses 25: 400-402.

Inoue, I. 1955. Synopsis of Japanese Gordiacea, with a note on a new species. Bulletin of the Biogeographical Society of Japan 16-19: 31-35. [In Japanese with English résumé and fig. ure caption]

Inoue, I. 1965. Nematomorpha. Pp. 465-466. In: Okada, K., Uchida, S. and Uchida, T. (Eds) New Illustrated Encyclopedia of the Fauna of Japan [I]. Hokuryukan, Tokyo. [In Japanese]

Inoue, I. 1972. The fauna of the lava caves around Mt. Fuji-san. VIII. Gordiacea. Bulletin of the National Science Museum, Tokyo 15: 167-169.

Inoue, I. 1979. Two new species of Gordius (Gordioidea) from Japan. Annotationes Zoologicae Japonenses 52: 235-239.

Inoue, I. 1994. Gordiod specimens deposited at the Toyama Science Museum. Bulletin of the Toyama Science Museum (17): 101-103. [In Japanese]

Inoue, I. and Fukui, T. 1953. A note on a new species of Gordius from Japan. Bulletin of the Tokyo Gakugei University 4: 37-39.

Schmidt-Rhaesa, A. 1997. Nematomorpha. In: Schwoerbel, J. and Zwick, P. (Eds) Süßwasserfauna von Mitteleuropa, Vol. 4/4. Gustav Fischer, Stuttgart, 124+(4) pp.

Schmidt-Rhaesa, A. 2001a. Problems and perspectives in nematomorph systematics. Organisms, Diversity \& Evolution 1: 161-163.

Schmidt-Rhaesa, A. 2001b. Variation of cuticular characters in the Nematomorpha: studies on Gordionus violaceus (Baird, 1853) and G. wolterstorffi (Camerano, 1888) from Britain and Ireland. Systematic Parasitology 49: 41-57.

Schmidt-Rhaesa, A. 2002a. Australian species of Chordodes (Nematomorpha) with a description of two new species, remarks on the genus and its life history. Journal of Natural History $36: 1569-1588$.

Schmidt-Rhaesa, A. 2002b. Are the genera of Nematomorpha monophyletic taxa? Zoologica Scripta 31: 185-200.

Schmidt-Rhaesa, A., Thomas, F. and Poulin, R. 2000. Redescription of Gordius paranensis Camerano, 1892 (Nematomorpha), a species new for New Zealand. Journal of Natural History 34: 333-340.

Smith, D. G. 1994. A reevaluation of Gordius aquaticus difficilis Montgomery, 1898 (Nematomorpha, Gordioidea, Gordiidae). Proceedings of the Academy of Natural Sciences of Philadelphia 145: 29-34.

Yamaguti, S. 1943. Saitenwürmer in Japan, I. Paragordionus kawamurai n. sp. Bulletin of the Biogeographical Society of Japan 13: 65-68. 